\title{
PENGUJIAN ANOMALI PASAR (JANUARY EFFECT) DI BURSA EFEK INDONESIA
}

\author{
Ni Kadek Ema Yunita ${ }^{1}$ \\ Henny Rahyuda ${ }^{2}$
${ }^{1,2}$ Fakultas Ekonomi dan Bisnis Universitas Udayana (Unud), Bali, Indonesia
email: kadekemayunita@gmail.com

\begin{abstract}
ABSTRAK
January effect adalah salah satu fenomena penyimpangan terhadap bentuk pasar modal efisien, dimana rata-rata return bulan Januari cenderung lebih tinggi dibandingkan dengan bulan-bulan lainnya. Penelitian ini bertujuan untuk mengidentifikasi apakah terdapat January effect pada saham perusahaan indeks IDX30 di Bursa Efek Indonesia periode Pebruari 2013 hingga Januari 2018. Penelitian ini menggunakan data sekunder yang berupa data harga saham per bulan yang digunakan yaitu harga penutupan di Bursa Efek Indonesia. Sampel yang digunakan yaitu 17 perusahaan yang secara bertrut-turut masuk kedalam kelompok indeks IDX30 selama periode penelitian. Hasil pengujian menggunakan program SPSS yaitu t-test yang menunjukkan bahwa tidak terdapat perbedaan abnormal return saham bulan Januari dengan bulan lainnya sehingga dapat ditarik kesimpulan bahwa fenomena January Effect tidak terjadi di pasar modal Indonesia. Kata kunci: january effect, abnormal return, indeks IDX30
\end{abstract}

\section{ABSTRACT}

The January effect is a phenomenon of deviation from the form of efficient capital markets, where the average return in January is higher than in other months. The purpose of this research is to find out whether there is a January effect on the IDX30 index group companies on the Indonesia Stock Exchange in the period February 2013 to January 2018. This study uses secondary data in the form of monthly stock price data used closing price on the Indonesia Stock Exchange. The sample used was 17 companies. The test results using the SPSS program is a t-test which shows that there is no difference in abnormal stock returns in January with months other than January. So, it can be concluded that the phenomenon of the January Effect does not occur in the Indonesian capital market.

Keywords: january Effect, abnormal return, IDX30 Index 


\section{PENDAHULUAN}

Dunia perekonomian dan investasi yang semakin berkembang menyebabkan minat masyarakat meningkat untuk berinvestasi. Menurut Sunariyah (2011: 4), investasi adalah penanaman modal untuk satu atau lebih aktiva yang dimiliki biasanya berjangka waktu panjang dengan harapan mendapat keuntungan di masa yang akan datang. Salah satu sarana yang dapat dipergunakan untuk melakukan kegiatan investasi oleh masyarakat yaitu pasar modal.

Pasar modal adalah tempat bertemunya penjual dan pembeli untuk melakukan kegiatan perdagangan yang berhubungan dengan modal perusahaan publik seperti jual beli efek. Pasar modal merupakan pasar untuk berbagai instrumen keuangan jangka panjang (umumnya lebih dari satu tahun) yang bisa diperjual-belikan, seperti obligasi (surat utang), saham (ekuitas), instrumen derivatif, maupun instrumen lainnya. Pasar modal berfungsi sebagai lembaga perantara, dimana pasar modal dapat menghubungkan penjual dengan pembeli sehingga pasar modal ini dapat memfasilitasi berbagai sarana dan prasarana kegiatan jual beli dan kegiatan lainnya, (www.idx.co.id).

Salah satu konsep pasar modal yang mulai berkembang diantaranya adalah konsep pasar efisien. Konsep pasar efisien menyiratkan adanya suatu proses penyesuaian harga sekuritas menuju harga keseimbangan yang baru, sebagai respon atas informasi baru yang masuk ke pasar (Tandelilin, 2010: 218). Efisiensi pasar dibagi menjadi dua, yaitu secara eksternal dan internal. Efisiensi pasar eksternal membuktikan pasar telah berada pada keadaan seimbang sehingga informasi yang beredar tidak dapat memberikan keuntungan diatas rata-rata. Efisiensi pasar internal yaitu pasar modal memberikan informasi melalui harga yang beredar dan jasa yang dibutuhkan oleh para investor dengan harga murah.

Teori efisiensi pasarpertama kali ditemukan oleh Fama pada tahun 1970. Pasar disebut efisien apabila tidak ada satupun investor yang mampu mendapatkan informasi lebih sehingga memeroleh return tak normal (abnormal return). Hal ini tentunya disesuaikan dengan risiko dan menggunakan strategi perdagangan yang tersedia. Fama (1970), mengategorikan bentuk pasar yang efisien ke dalam tiga efficient market hypothesis yakni pasar efisien dalam bentuk lemah (weak form), pasar efisien dalam bentuk setengah kuat (semi strong), dan pasar efisien dalam bentuk kuat (strong form) (Tandelilin, 2010: 223).

Berlawanan dengan konsep pasar efisien, terdapat banyak penelitian yang menyebutkan adanya asimetri informasi dikalangan investor, (Sari, 2014). Asimetri informasi adalah suatu kondisi dimana pelaku pasar tidak memiliki informasi yang sama antara satu dengan yang lainnya (Hartono 2017: 629). Asimetri informasi ini dapat dibuktikan dengan ditemukannya pembiasan/penyimpangan yang biasa disebut dengan anomali pasar. Munculnya anomali pasardikarenakan terciptanya return tak normalpada aktivitas pergerakan harga saham. Terdapat beberapa jenis anomali pasar yang biasa terjadi yaitu anomali perusahaan, anomali musiman, anomali peristiwa, dan anomali akuntansi.

Para investor perlu berhati-hati dalam memaksimalkan masalah anomali pasar. Tidak ada yang menjamin investor bahwa anomali pasar dapat mendukung pengambilan keputusan investasi. Hal inidikarenakanhasil pengujian secara nyata tentang anomali pasar bukan merupakan strategi investasi. Oleh karena itu, 
investor perlu berhati-hati dalam menerapkan strategi timing jual beli saham yang tepat untuk memanfaatkan anomali tersebut (Surjoko, 2014).

Salah satu jenis dari anomali pasar yang sering dijumpai yaitu anomali musiman (seasonal anomalies/calendar effect). Seasonal anomalies/calendar effect merupakan penyimpangan yang terkait dengan efek ekonomi yang terkait dengan kalender atau bulan perdagangan. Efek yang ditimbulkan ini meliputi perilaku yang berbeda dari pasar saham terkait dengan waktu-waktu perdagangan di pasar modal. Alasan digunakannya anomali musiman dalam penelitian yaitu dikarenakan adanya peristiwa yang tidak sesuai dengan teori hipotesis pasar efisien yang bersifat musiman dan terjadi secara berulang pada waktu-waktu tertentu. Adanya pola musiman harga di masa lalu, maka investor dapat memeroleh return tak normal (abnormal return) diamana January Effect merupakan salah satu bagian dari anomali musiman.

January effect adalah suatu penyimpangan dimana return di bulan Januari mengalami peningkatan yang signifikan dibandingkan dengan bulan lainnya selain Januari. January effect merupakan suatu kejadian yang berkaitan dengan adanya perubahan tahun pajak dimana akhir tahun pajak dii bulan Desember dan awal tahun pajak terjadi di bulan Januari.Hal-hal yang dapat memicu terjadinya fenomenajanuary effect ini yaitu adanya pengurangan pajak yang timbul dikarenakan penjualan saham pada akhir tahun, mewujudkancapital gain, pengaruh portofolio window dressing, atau penjualan saham oleh investor untuk liburan (Pratomo, 2007).

Akhir tahun merupakaan saat dimana kebanyakan fund manager menyarankan investor untuk melakukan penjualan saham yang merugi dan menyarankan investor untuk membeli saham tersebut kembali pada awal tahun. Hal ini dikarenakan manajer investasi ingin memperbaiki laporan kinerja portofolio saham. Tindakan inilah yang akan menciptakan pengurangan pajak (tax-loss) bagi investor serta menyebabkan penurunan harga di akhir tahun dan kenaikan di awal tahun yang dipicu dari permintaan dan penawaran saham, sehingga akan memeroleh return yang tinggi di bulan Januari (Tandelilin, 2010: 231).

Tujuan investor dalam berinvestasi adalah memaksimalkan return. Return merupakan salah satu faktor yang memotivasi investor berinvestasi dan juga merupakan imbalan dari risiko yang ditanggung investor dalam melakukan investasi. Return dibedakan menjadi tiga yaitu return realisasi, return ekspektasi, dan return tak normal. Return realisasi(realized return) merupakan return yang telah terjadi dan penghitungannya menggunakan data historis perusahaan. Return ekspektasi (expected return) adalah return yang diharapkan akan diperoleh oleh investor dimasa mendatang. Return tak normal (abnormal return) adalah selisih antara realized return dengan expected return.

Terjadinya January Effect dapat ditunjukkan dengan adanya return tak normal (abnormal return) yang didapatkan oleh investor. Penelitian Hamid dan Habisb (2017) tentang pengaruh antara January Effect terhadap return saham perusahaan kecil di Amerika Serikat merepresentasikan bahwa terjadi January Effect sehingga menimbulkan abnormal return, penelitian Manggala \& Lohia (2013) tentang keberadaan month-of-the-year effect terhadap return saham di 
kawasan Asia Pasifik, serta penelitian Chou et al. (2011) tentang return saham dan January Effect. Hal ini sejalan dengan ditemukannya fenomena January Effect di Bursa Efek Indonesia oleh Fitriyani \& Sari (2013) serta Pradnyaparamita \& Rahyuda (2017) pada perusahaan LQ-45.

Tidak semua pasar modal menunjukkan adanya peristiwa January Effect. Ditemukannya January Effect hanya pada beberapa periode saja dan ada pula yang tidak sama sekali. January Effect sangat bergantung pada fenomena yang terjadi selama periode pengamatan. Hal inilah yang menyebabkan January Effect tidak selalu ditemukan pada setiap periode pengamatan karena bergantung pada tindakan investor dalam menginterpretasikan setiap fenomena yang terjadi untuk mendapatkan return yang lebih tinggi.

Bukti tidak ditemukannya January Effect dapat dilihat pada penelitianpenelitian berikut. Penelitian Kemal \& Sinem (2016) tentang pengujian January Effect di Bursa Istanbul, penelitian Jaisinghani (2016) dan Patel (2016) tentang pengujian January Effect terhadap return saham di Amerika Serikat, penelitian Atsin \& Ocran (2015) tentang pengujian calendar effects dan market anomalies di Johannesburg Stock Exchange, serta penelitian Angelovska (2014) menemukan tidak ada perbedaan secara signifikan antara return saham bulan Januari dengan bulan lainnya. Penelitian Compton et al. (2013) tentang anomali kalender di Bursa Saham Rusia. Selain itu, penelitian Sriram \& Devi (2013), Darrat et al. (2013), Luhan et al. (2011), Yatiwella \& Silva (2011) menemukan bahwa January Effect tidak memberikan pengaruh yang signifikan terhadap return saham. Hal ini sejalan dengan tidak ditemukannya January Effect di Bursa Efek Indonesia dan Bursa Saham Shanghai oleh (Kartikasari, 2017). Deannes \& Isynuwardhana (2015) serta Sari \& Sisdyani (2014) yang juga menemukan bahwa tidak terdapat perbedaan return saham pada bulan Januari dan selain bulan lainnya di Bursa Efek Indonesia. Begitu pula dengan Penelitian Kadir (2014) yang tidak menemukan pengaruh dari fenomena January Effect pada perusahaan LQ45 di Bursa Efek Indonesia periode 2010 hingga 2013.

Penelitian ini dilakukan di Bursa Efek Indonesia dengan menggunakan data pada Indeks IDX30. Indeks IDX30 merupakan indeks yang pemilihan saham perusahaannya diambil dari konstituen indeks LQ45. Pengambilan keputusan menggunakan Indeks IDX30 adalah faktor kuantitatif yang terkait dengan total hari transaksi, nilai dan aktivitas transaksi saham tinggi, serta kapitalisasi pasar yang tinggi. Penelitian dilakukan menggunakan Indeks IDX30 karena indeks ini dapat dikatakan sebagai indeks yang cukup peka terhadap informasi-informasi pasar, (www.idx.co.id). Penelitian dilakukan pada periode Pebruari 2013 hingga Januari 2018 guna memperoleh data terbaru.

Berdasarkan research gap atau hasil penelitian yang berbeda mengenai January Effect, tentunya penelitian tentang dampak January Effect menarik untuk diteliti di pasar modal Indonesia. Oleh karena itu, penulis mengangkat judul "Pengujian Anomali Pasar (January Effect) di Bursa Efek Indonesia".Penelitian ini bertujuan untuk mengetahui apakah terdapat perbedaan abnormal return saham pada bulan Januari dan bulan selain Januari pada kelompok saham indeks IDX30 di Bursa Efek Indonesia. 
Pada bidang keuangan, konsep pasar efisien lebih menitikberatkan pada aspek informasi. Pasar yang efisien adalah pasar dimana semua harga sekuritas (saham) yang diperjual-belikansudah mencerminkan seluruh informasi yang tersedia. Informasi yang tersedia dapat meliputi semua informasi yang tersedia baik informasi di masa lalu, informasi saat ini, serta informasi yang bersifat sebagai pendapat atau opini rasional yang beredar di pasar dan dapat memengaruhi perubahan harga saham (Tandelilin, 2010: 219).

Proses bereaksinya pasar terhadap informasi agar mencapai harga keseimbangan yang baru merupakan hal yang penting. Jika pasar bereaksi dengan cepat dan tepat untuk mencapai harga keseimbangan baru yang seluruhnya mencerminkan semua informasi yang ada, maka kondisi pasar sudah dapat dikatakan efisien. Jadi, terdapat hubungan antara teori pasar modal yang menjelaskan keadaan keseimbangan dengan konsep pasar efisien yang menjelaskan bagaimana pasar memproses informasi untuk menuju pada posisi keseimbangan yang baru (Hartono, 2017: 605).

Tandelilin (2010: 219) menjelaskan konsep pasar efisien menyiratkan adanya suatu proses penyesuaian harga sekuritas menuju harga keseimbangan yang baru, sebagai respon atas informasi baru yang masuk ke pasar. Meskipun proses penyesuaian harga tidak harus berjalan dengan sempurna, tetapi yang dipentingkan adalah harga yang terbentuk tersebut tidak bias. Dengan demikian, pada waktu tertentu pasar bisa overadjusted atau underadjustice ketika bereaksi terhadap informasi baru, sehingga harga baru yang terbentuk tersebut bisa jadi bukan merupakan harga yang mencerminkan nilai intrinsik dari sekuritas tersebut. Harga keseimbangan akan terbentuk setelah investor sudah sepenuhnya menilai dampak dari informasi tersebut.

Ide dari pengujian pasar yang efisien dijelaskan dalam Hipotesis Pasar Efisien (HPE) atau Efficient Market Hypothesis (EMH). Untuk mengetahui kebenaran dari hipotesis ini, maka perlu dilakukan pengujian secara empiris untuk masing-masing bentuk efisiensi pasar. Fama (1970) membagi pengujian efisiensi pasar menjadi tiga kategori yaitu: 1) Pengujian bentuk lemah (weak form test), yaitu seberapa kuat informasi masa lalu dapat memprediksi return di masa depan. Fama mengungkapkan pengujian terhadap pendugaan return (test for return predictability). 2) Pengujian bentuk setengah kuat (semi-strong form test), yaitu seberapa cepat harga sekuritas merefleksikan informasi yang dipublikasikan. Pengujian ini kemudian diubah menjadi studi peristiwa (event studies). 3) Pengujian bentuk kuat (strong form test), yaitu untuk menjawab pertanyaan apakah investor memiliki informasi privat yang tidak terefleksi di harga sekuritas. Selanjutnya, pengujian ini diubah menjadi pengujian terhadap informasi privat (tests for private information).

Jones (1996) mendefinisikan anomali pasar (market anomaly) sebagai teknik atau strategi yang bertentangan dengan pasar efisien (Hartono, 2017: 664). Levy mengemukakan dalam teori keuangan anomali pasar dikategorikan ke dalam empat macam yaitu anomali perusahaan, anomali musiman, anomali peristiwa, dan anomali akuntansi (Alteza, 2007). Anomali pasar adalah teknik-teknik atau strategi-strategi yang bertentangan dengan konsep pasar modal efisien (Jones 2014: 311). Penyebab kejadian anomali pasar ini tidak dapat dijelaskan dengan 
mudah. Beberapa anomali yang terdapat di pasar modal antara lain: 1) Day of The Week Effect atau Efek Hari Perdagangan adalah anomali saat perbedaan hari perdagangan berpengaruh terhadap pola return saham dalam satu minggu. 2) Price Earning (P/E) Effect adalah anomali yang memperlihatkan saham dengan $\mathrm{P} / \mathrm{E}$ rendah menunjukkan risk adjusted return yang lebih tinggi dibandingkan dengan saham yang memiliki P/E tinggi (Jones, 2014: 313). 3) Size Effect adalah anomali dimana perusahaan ukuran kecil menunjukkan risk adjusted return tinggi secara rata-rata dibandingkan perusahaan dengan ukuran besar. 4) January Effect adalah fenomena di pasar modal dimanareturn saham di bulan Januari cenderung mengalami kenaikan dibandingkan bulan-bulan lainnya (Jones, 2014: 314). 5) Neglected Firm Effect adalah anomali dimana terdapat kecenderungan bahwa investasi pasar saham pada perusahaan yang kurang terkenal dapat memberikan tingkat keuntungan yang lebih besar. 6) Reversal Effect merupakan efek pembalikan rata-rata return atau biasa disebut dengan anomali winner-loser yaitu kecenderungan saham yang memiliki kinerja buruk (loser) akan berbalik menjadi saham yang memiliki kinerja baik (winner) pada periode berikutnya, begitu pula sebaliknya.

penyebab yang menguatkan terjadinya fenomena January Effect yaitu: 1) Window dressing merupakan strategi yang digunakan manajer investasi untuk memperbaiki laporan kinerja portofolio saham. Sebagian besar investor menjual saham dengan kapitalisasi buruk di akhir tahun dan memperbaiki laporan penjualan dengan membeli saham berkapitalisasi baik di awal tahun. Hal inilah yang memicu terbentuknya pola pikir investor yang akhirnya dapat memunculkan fenomena January effect menurut Sharpe (Pratomo, 2007). 2) Tax-loss selling yaitu penjualan saham yang berkinerja buruk di akhir tahun. Tujuan dari penjualan saham ini yaitu untuk membenahi laporan keuangan yang akan berdampak pada menurunnya pembayaran hutang pajak (Fauzi, 2007). Dampak dari hal ini yaitu investor menjual saham dengan kapitalisasi buruk di akhir tahun dan membeli saham dengan kapitalisasi baik di awal tahun. Menurut Contigeat dan Pandey hal inilah yang menyebabkan keuntungan tinggi di bulan Januari. 3) Small stock's bettamerupakan fenomena dimana January Effect cenderung terjadi pada perusahaan yang berkapitalisasi kecil (Pratomo, 2007). Penelitian sebelumnya menemukan bahwa sebagian besar beta saham pada perusahaanberkapitalisasi kecil memiliki kecenderungan mengalami peningkatan yang signifikan dibandingkan dengan perusahaan yang berkapitalisasi besar.

Perkembangan pasar modal diiringi dengan berkembangnya fungsi indeks yang tidak hanya sebagai indikator pergerakan harga saham, namun juga dapat digunakan sebagai underlyng dari sebuah produk investasi seperti ETF, reksa dana, maupun produk derivatif lainnya seperti option atau future. Untuk memenuhi kebutuhan tersebut, Bursa Efek Indonesia mengeluarkan sebuah indeks baru yaitu indeks IDX30.

Saham adalah salah satu instrumen pasar keuangan yang paling dominan diperdagangkan. Saham merupakan surat berharga sebagai bukti penyertaan atau pemilikan individu maupun institusi dalam suatu perusahaan. Sekuritas (saham) menunjukkan hak pemodal untuk memeroleh bagian dari prospek atau kekayaan organisasi yang menerbitkan sekuritas tersebut dan berbagai kondisi yang 
memungkinkan pemodal tersebut menjalankan haknya. Saham berwujud selembar kertas yang menerangkan bahwa pemilik kertas adalah pemilik perusahaan yang menerbitkan surat berharga tersebut.

Terdapat dua keuntungan yang diperoleh investor dengan membeli atau memiliki saham, yaitu dividen dan capital gain. Dividen adalah pembagian keuntungan yang diberikan perusahaan penerbit saham tersebut atas keuntungan yang dihasilkan perusahaan, dividen diberikan setelah mendapat persetujuan dari pemegang saham dalam Rapat Umum Pemegang Saham (RUPS). Dividen yang dibagikan perusahaan dapat berupa dividen tunai dimana setiap pemegang saham diberikan dividen berupa uang tunai dalam jumlah rupiah tertentu untuk setiap saham atau dapat pula berupa dividen stock dimana setiap pemegang saham diberikan dividen sejumlah saham yang dimiliki investor bertambah dengan adanya pembagian dividen stock. Sedangkan capital gain merupakan selisih antara harga beli dan harga jual saham, dimana harga jual lebih tinggi dibandingkan harga beli saham. Capital gain dibentuk dengan adanya aktivitas perdagangan di pasar sekunder.

Return merupakan hasil yang diperoleh dari kegiatan investasi. Investasi dalam bentuk saham akan menghasilkan return di masa depan bagi para investor. Tanpa adanya tingkat keuntungan yang dihasilkan dari suatu investasi, maka investor tidak akan tertarik untuk melakukan kegiatan investasi. Jadi, seluruh kegiatan investasi mempunyai tujuan utama yaitu untuk mendapatkan return. Hartono (2017: 283), return merupakan hasil yang diperoleh dari kegiatan investasi. Brigham dan Houston (2006: 215) mendefinisikan return atau tingkat pengembalian adalah selisih antara jumlah yang diterima dan jumlah yang diinvestasikan, dibagi dengan jumlah investasi. Sehingga dapat disimpulkan bahwa return saham merupakan tingkat pengembalian berupa imbalan yang diperoleh dari hasil jual beli saham.

Return saham dapat dibedakan menjadi dua jenis yaitu return realisasi dan return ekspektasi (Hartono, 2017: 283). Return realisasi dapat digunakan sebagai salah satu pengukuran kinerja perusahaan dan dapat digunakan sebagai dasar penentu return ekspektasi dan risiko di masa yang akan datang. Return ekspektasi merupakan return yang diharapkan terjadi di masa mendatang dan masih bersifat tidak pasti.

Sumber-sumber return investasi terdiri dari dua komponen utama, yaitu yield dan capital gain (loss). Yield merupakan komponen utama return yang mencerminkan aliran kas atau pendapatan yang diperoleh secara periodik dari suatu investasi. Yield ditunjukkan oleh besarnya dividen yang diperoleh. Capital gain sebagai komponen kedua dari return merupakan kenaikan atau penurunan harga suatu surat berharga yang bisa berupa saham maupun surat hutang jangka panjang, dan yang bisa memberikan keuntungan (capital gain) maupun kerugian (capital loss) bagi investor.

Indeks IDX30 diluncurkan pada 23 April 2012. Indeks IDX30 adalah indeks yang terdiri dari 30 saham yang konstituennya dipilih dari kelompok indeks LQ45. Kelompok Indeks LQ45 dipilih karena telah menggambarkan kinerja saham dengan kapitalisasi pasar besar. Namun, beberapa manajer investasimenganggap jumlah 45 saham tersebut terlalu besar. Jumlah konstituen 
Indeks IDX30 yang terdiri dari 30 saham memiliki keunggulan lebih mudah dilakukan replika sebagai acuan portofolio. Selain itu, menurut teori portofolio jumlah 30 merupakan jumlah diversifikasi aset yang ideal dalam sebuah portofolio (www.idx.co.id).

Penentuan saham dilaksanakan setiap 6 bulan, yaitu pada awal bulan Pebruari dan Agustus. Tanggal basis perhitungan adalah 30 Desember 2004 dengan nilai awal indeks adalah 100 yang dihitung sama dengan indeks lain yaitu menggunakan rata-rata timbangan kapitalisasi pasar (value wighted) (Hartono, 2017: 179). Kriteria pemilihan saham pada indeks IDX30 adalah faktor kuantitatif yang terkait dengan total hari transaksi, nilai dan aktivitas transaksi saham tinggi, serta kapitalisasi pasar yang tinggi. Aspek kualitatif yang juga dipertimbangkan adalah kondisi keuangan, prospek pertumbuhan, dan faktorfaktor lain yang berhubungan dengan pertumbuhan perusahaan (Hartono, 2017: 179). Sehingga Indeks IDX30 cukup efektif untuk menggambarkan pergerakan saham dengan kapitalisasi pasar besar.

Konsep pasar modal yang berkembang saat ini yaitu konsep pasar modal efisien (Husnan, 2005: 259). Pada konsep pasar modal efisien harga-harga aset maupun sekuritas secara cepat mencerminkan informasi yang tersedia. Pasar dikatakan efisien apabila tidak ada individu ataupun investor yang akan mampu memeroleh abnormal return, setelah diselaraskan dengan risiko dan strategi perdagangan yang tersedia. Harga-harga yang terbentuk di pasar mencerminkan informasi yang ada atau stock price reflect all avalaible information.

Fama (1991) pada periode 1941-1981 menemukan bahwa return bulan Januari lebih tinggi jika dibandingkan dengan bulan-bulan lainnya dan perbedaan yang lebih besar terjadi pada saham dengan nilai kapitalisasi pasar yang kecil. Periode 1982 sampai dengan Januari 1991, Fama juga menemukan hal yang sama tetapi perbedaan return bulan Januari untuk small stock dan larger stock tidak terlalu signifikan. Return tak normal bulan Januari untuk small stock umumnya relatif tinggi pada hari-hari di awal bulan.

Berlainan dengan konsep pasar efisien, banyak peneliti pasar yang menemukan adanya anomali, yaitu peristiwa yang tidak diantisipasi dan yang menawarkan investor peluang untuk memperoleh abnormal return. Anomali yang paling sering diteliti salah satunya adalah anomali musiman (seasonal anomalies) yaitu anomali yang terkait dengan waktu-waktu perdagangan pasar yang terjadi pada pasar modal. Salah satu kategori anomali musiman adalah january effect. January effect adalah anomali yang menunjukkan bahwa return di bulan Januari ditemukan cenderung lebih tinggi dibandingkan bulan lain.

Beberapa peneliti sebelumnya telah menenmukan adanya anomali ini diantaranya Pradnyaparamitha (2017) menemukan adanya January Effect di Bursa Efek Indonesia pada perusahaan LQ-45. Fitriyani dan Sari (2013) menyatakan bahwa Fenomena January Effect terjadi selama periode 2009-2011 ditandai dengan adanya return pasar pasar pada bulan Januari lebih tinggi dan signifikan.

Hamid \& Habisb (2017) menemukan adanya fenomena January Effect di New York Stock Exchange, begitu pula penelitian Sudarvel \& Velmurugan (2015) menemukan hal yang sama di Bursa Efek India. Jadi, penelitian ini telah membuktikan secara empiris bahwa terdapat fenomena January Effect pada 
kelompok saham indeks IDX30 di Bursa Efek Indonesia pada periode Pebruari 2013 sampai dengan Januari 2018.

Berdasarkan uraian di atas maka dirumuskan hipotesis sebagai berikut:

$\mathrm{H}_{1}$ : Terdapat perbedaan abnormal return pada bulan Januari dan bulan selain Januari pada kelompok saham Indeks IDX30 di Bursa Efek Indonesia.

\section{METODE PENELITIAN}

Penelitian ini adalah penelitian kuantitatif yang menitikberatkan pengukuran variabel pada pengujian teori-teori dengan angka dan melakukan analisis data dengan prosedur statistik untuk menguji hipotesis. Menurut jenisnya penelitian ini merupakan penelitian komparatif. Menurut Sugiyono (2017: 20) peneltian komparatif adalah suatu penelitian yang bersifat membandingkan antara variabel satu dengan variabel lainnya. Ruang lingkup penelitian ini yaitu saham-saham perusahaan di Bursa Efek Indonesia yang tergolong dalam kelompok saham indeks IDX30 selama periode penelitian Pebruari 2013 hingga Januari 2018. Obyek penelitian pada penelitian ini adalah saham-saham perusahaan di Bursa Efek Indonesia yang masuk secara terus-menerus dalam kelompok saham IDX30 selama periode Pebruari 2013 hingga Januari 2018. Hal ini dikarenakan indeks IDX30 merupakan indeks yang terdiri dari 30 saham yang konstituennya dipilih dari indeks LQ45 sehingga menyebabkan indeks ini peka terhadap informasi.

Penelitian ini menggunakan variabelabnormal return saham perusahaan pada bulan Januari dan bulan selain Januari pada indeks IDX30 untuk periode Pebruari 2013 hingga Januari 2018.

Abnormal returnadalah selisih darireturnsahamyang sesungguhnya terjadi (actual return) terhadap return pasar (market return) (Hartono, 2017: 679). Secara sistematis, abnormal return dapat dirumuskan sebagai berikut :

$A R_{i t}=R_{i t}-R_{m, t}$

Keterangan :

$\mathrm{AR}_{\text {it }}=$ Abnormal return (Persentase);

$\mathrm{R}_{\mathrm{it}} \quad=$ Returnmasing-masing saham perusahaan (Rupiah); dan

$R_{m, t} \quad=$ Return pasar(Rupiah)

Return saham yang digunakan adalah return yang sesungguhnya terjadi (actual return) yaitucapital gain atau capital loss. Capital gain atau capital loss adalah selisih antara harga saham periode sekarang dengan harga saham pada periode sebelumnya pada perusahaan yang masuk secara terus menerus ke dalam kelompok saham IDX30 periode Pebruari 2013 hingga Januari 2018. Secara sistematis actual return dapat diformulasikan sebagai berikut (Hartono, 2017: 284):

$R_{i, t}=\frac{P_{t}-P_{t-1}}{P_{t-1}} \times 100 \%$

Keterangan :

$\mathrm{R}_{\mathrm{it}} \quad=$ Return saham $i$ pada periode $t$ (Rupiah);

$\mathrm{P}_{\mathrm{t}} \quad=$ Harga investasi saat ini (Rupiah); dan

$\mathrm{P}_{\mathrm{t}-1} \quad=$ Harga investasi sebelumnya ( $\left.\mathrm{t}-1\right)$ (Rupiah).

Return ekspektasi (expected return) merupakan return yang diharapkan 
akan diperoleh oleh investor dimasa yang akan datang (Hartono, 2017: 300). Return ekspektasidapat dihitungdengan indeks pasar IDX30, yaitu melalui selisih antara indeks pasar IDX30 pada bulan ini dengan indeks pasar IDX30 bulan sebelumnya, dengan rumus:

$R_{m, t}=\frac{\text { Indeks IDX } 30_{t}-\text { Indeks IDX } 30_{t-1}}{\text { Indeks IDX } I 0_{t-1}}$

Keterangan :

$R_{m, t}=$ Return pasar(Rupiah)

Jenis data yang digunakan dalam penelitian ini adalah data kuantitatif. Data kuantitatif adalah data yang berbentuk angka atau data kualitatif yang diangkakan atau scoring (Sugiyono, 2015:28). Data kuantitatif dalam penelitian ini adalah berupa close price saham dari berbagai saham yang masuk ke dalam perhitungan indeks IDX30 selama periode Pebruari 2013 hingga Januari 2018 di Bursa Efek Indonesia (BEI).

Data yang dipergunakan pada penelitian ini adalah data sekunder. Data-data tersebut merupakan perkembangan harga saham yang termasuk dalam kelompok indeks IDX30 selama periode Pebruari 2013 hingga Januari 2018 yang dapat diakses melalui website Bursa Efek Indonesia dan Yahoo Finance.

Populasi dalam penelitian ini yaitu saham perusahaan di Bursa Efek Indonesia yang masuk ke dalam kelompok indeks IDX30, dengan pertimbangan indeks IDX30 merupakan indeks dengan 30 saham kapitalisasi terbesar dari indeks LQ45 yang memiliki kapitalisasi pasar yang paling tinggi dan aktif diperdagangkan sehingga menyebabkan indeks ini menjadi indeks yang cukup sensitif terhadap informasi-informasi pasar.

Sampel dalam penelitian ini adalah semua perusahaan yang masuk ke dalam kelompok saham indeks IDX30 periode Pebruari 2013 sampai dengan Januari 2018. Adapun kriteria sampel dalam penelitian yaitu perusahaan yang secara terus-menerus tergabung dalam indeks IDX30 selama Pebruari 2013 sampai dengan Januari 2018.

Tabel 1.

Penentuan Sampel Penelitian

\begin{tabular}{clc}
\hline No & \multicolumn{1}{c}{ Keterangan } & \multicolumn{1}{c}{$\begin{array}{c}\text { Jumlah } \\
\text { Perusahaan }\end{array}$} \\
\hline 1 & $\begin{array}{l}\text { Perusahaan-perusahaan yang masuk dalam indeks IDX30 } \\
\text { selama periode Pebruari 2013 sampai Januari 2018 }\end{array}$ & 47 \\
& $\begin{array}{l}\text { Perusahaan yang tidak secara terus-menerus muncul dalam } \\
\text { indeks IDX30 selama periode Pebruari 2013 sampai Januari }\end{array}$ & $(30)$ \\
& $\begin{array}{l}\text { 2018 } \\
\text { Total Sampel }\end{array}$ & $\mathbf{1 7}$ \\
\hline
\end{tabular}

Sumber: Data diolah, 2018

Pengumpulan data dilakukan dengan menggunakan metodeobservasi non partisipan. Observasi dilakukan melalui pencarian informasi melalui buku dan jurnal yang berkaitan dengan analisis dan pembahasan menegnai January 
Effect,sehingga memeroleh dasar teori dan informasi yang mendukung. Data yang dikumpulkan mencakup data perkembangan harga saham yang masuk ke dalam kelompok saham indeks IDX30 selama periode Pebruari 2013 hingga Januari 2018 melalui website Bursa Efek Indonesia (BEI) dan Yahoo Finance.

Penelitian ini menggunakan teknik analisis data uji beda $t$-test. Tujuan dari pengujian ini yaitu untuk membuktikan apakah terdapat perbedaan abnormal return pada bulan Januari dibandingkan dengan bulan lainnya secara signifikan. Uji beda berpasangan (Paired Sample $t$-test) adalah uji yang digunakan, dimana uji ini berfungsi untuk membuktikan ada atau tidaknya hubungan antara dua sample yang tidak berhubungan memiliki perbedaan nilai rata-rata (Ghozali, 2016: 64). Berikut merupakan formulasi dari uji beda t-test yaitu :

$\mathrm{t}=\frac{\text { Rata-rata sampel pertama- Rata-rata sampel kedua }}{\text { Standar error perbedaan rata-rata kedua sampel }} \times 100 \%$

\section{HASIL DAN PEMBAHASAN}

Pasar modal (capital market) merupakan pasar untuk berbagai instrumen keuangan jangka panjang yang dapat diperjual-belikan, baik surat utang (obligasi), ekuitas (saham), reksa dana, instrumen derivatif maupun instrumen lainnya, (www.idx.co.id). Pasar modal secara umum adalah tempat bertemunya penjual dan pembeli untuk melakukan kegiatan perdagangan yang berhubungan dengan modal perusahaan publik seperti jual beli efek. Secara historis pasar modal hadir sejak zaman kolonial Belanda pada tahun 1912 di Batavia. Pasar modal saat itu didirikan oleh pemerintah Hindia Belanda (VOC).

Bursa Batavia ditutup selama Perang Dunia I berlangsung dan kembali dibuka pada tahun 1925. Selain Bursa Batavia, pemerintah kolonial Belanda juga mengoperasikan bursa efek di Surabaya dan Semarang. Tahun 1939 dikarenakan isu politik (Perang Dunia II) Bursa Efek Semarang dan Surabaya ditutup. Pada tahun 1942-1951 Bursa Efek Jakarta ditutup kembali karena terjadi Perang Dunia II yang kemudian diikuti oleh perang kemerdekaan Republik Indonesia. Setelah pemerintahan Belanda mengakui kedaulatan Republik Indonesia pada tahun 1950, obligasi Republik Indonesia dikeluarkan oleh pemerintah. Peristiwa ini menandai mulai aktifnya kembali Pasar Modal Indonesia. Pada tahun 1952, bursa saham kembali beroperasi di Jakarta dengan memperdagangkan saham dan obligasi, namun terhenti kembali saat pemerintah meluncurkan program nasionalisasi pada tahun 1956.

Pada tahun 1977 Bursa Efek diresmikan oleh Presiden Soeharto. Bursa Efek Jakarta dijalankan dibawah BAPEPAM (Badan Pelaksana Pasar Modal) Tanggal 10 Agustus diperingatkan sebagai HUT Pasar Modal. Pengaktifan kembali pasar modal ini juga ditandai dengan go public PT Semen Cibinong sebagai emiten pertama Bursa Efek Jakarta. Pada tahun 1977-1987 perdagangan di Bursa Efek sangat lesu. Hal ini dikarenakan masyarakat lebih memilih instrumen perbankan dibandingkan instrumen pasar modal.

Pada tahun 1987, ditandai dengan hadirnya Paket Desember 1987 (PAKDES 87) yang memberikan kemudahan bagi perusahaan untuk melakukan penawaran umum dan bagi investor asing yang ingin menanamkan modal di Indonesia. Tahun 1989-1990 paket deregulasi di bidang Perbankan dan Pasar 
Modal diluncurkan. Hal ini ditandai dengan terbukanya Bursa Efek Jakarta untuk asing sehingga aktivitas bursa terlihat meningkat. Pada tanggal 2 Juni 1988 Bursa Paralel Indonesia (BPI) mulai beroperasi dan dikelola oleh Persatuan Perdagangan Utang dan Efek (PPUE), organisasi ini terdiri dari broker dan dealer. Selanjutnya, pada Desember 1988, pemerintah mengeluarkan Paket Desember 88 (PAKDES 88) yang memberikan kemudahan perusahaan untuk go public dan beberapa kebijakan lain yang positif bagi pertumbuhan pasar modal. Kegiatan perdagangan dan kapitalisasi pasar saham kembali meningkat seiring perkembangan pasar finansial dan sektor swasta, dimana puncak perkembangan terjadi pada tahun 1990.

Pada 13 Juli 1992, Bursa Efek Indonesia yang saat itu bernama Bursa Efek Jakarta (BEJ) diswastakan dan mulai beroperasi sebagai pasar saham di Indonesia. Swastanisasi bursa efek menjadi PT. Bursa Efek Jakarta ini mengakibatkan beralihnya fungasi BAPEPAM menjadi Badan Pengawas Pasar Modal. Tahun 1995, BEJ meluncurkan Jakarta Automated Trading System (JATS) yaitu sebuah sistem perdagangan otomatis yang menggantikan sistem perdagangan manual. Sistem ini memfasilitasi perdagangan saham dengan frekuensi yang lebih besar dan lebih menjamin kegiatan pasar yang adil dan transparan dibandingkan sistem perdagangan manual. Pada tanggal 10 Nopember 1995 pemerintah mengeluarkan Undang-Undang No. 8 Tahun 1995 tentang pasar modal. Undang-Undang ini mulai diberlakukan pada Januari 1996.

Pada tahun 2000, Bursa Efek Jakarta menerapkan sistem perdagangan tanpa warkat (scripless trading) yang memiliki tujuan untuk meningkatkan likuiditas pasar, menghindari peristiwa saham hilang, dan pemalsuan saham, serta mempercepat proses penyelesaian transaksi. Pada tahun yang sama pula Bursa Efek Jakarta menerapkan perdagangan jarak jauh (remote trading) sebagai upaya untuk meningkatkan akses pasar, efisiensi pasar, kecepatan, serta frekuensi perdagangan.

Pada tanggal 1 Desember 2007, Bursa Efek Jakarta dan Bursa Efek Surabaya melakukan penggabungan yang dikenal sebagai Bursa Efek Indonesia (BEI) atau Indonesian Stock Exchange (IDX). Penggabungan ini menjadikan Indonesia hanya memiliki satu pasar modal.

Penelitian ini menggunakan sampel yaitu saham yang secara terus menerus masuk ke dalam kelompok saham indeks IDX30 periode Pebruari 2013 hingga 2018. Saham kelompok indeks IDX30 adalah saham-saham perusahaan terpilih dengan total hari transaksi, nilai dan aktivitas transaksi saham tinggi, serta kapitalisasi pasar yang tinggi. Berikut merupakan sampel penelitian yaitu:

Tabel 2.

Daftar Perusahaan yang Masuk Indeks IDX30

Periode Pebruari 2013 - Januari 2018

\begin{tabular}{lll}
\hline No & $\begin{array}{l}\text { Kode Listing } \\
\text { Perusahaan }\end{array}$ & Nama Perusahaan \\
\hline 1 & ADRO & Adaro Energy Tbk. \\
2 & ASII & Astra International Tbk. \\
3 & BBCA & Bank Central Asia Tbk. \\
\hline
\end{tabular}

Bersambung... 
Lanjutan Tabel 2.

\begin{tabular}{lll}
\hline No & $\begin{array}{l}\text { Kode Listing } \\
\text { Perusahaan }\end{array}$ & Nama Perusahaan \\
\hline 4 & BBNI & Bank Negara Indonesia (Persero) Tbk. \\
5 & BBRI & Bank Rakyat Indonesia (Persero) Tbk. \\
6 & BMRI & Bank Mandiri (Persero) Tbk. \\
7 & GGRM & Gudang Garam Tbk. \\
8 & INDF & Indofood Sukses Makmur Tbk. \\
9 & INTP & Indocement Tunggal Perkasa Tbk. \\
10 & KLBF & Kalbe Farma Tbk. \\
11 & LPKR & Lippo Karawaci Tbk. \\
12 & MNCN & Media Nusantara Citra Tbk. \\
13 & PGAS & Perusahan Gas Negara (Persero) Tbk. \\
14 & SMGR & Semen Indonesia (Persero) Tbk. \\
15 & TLKM & Telekomunikasi Indonesia (Persero) Tbk. \\
16 & UNTR & United Tractors Tbk. \\
17 & UNVR & Unilever Indonesia Tbk. \\
\hline Sumber & Data diob, 2018
\end{tabular}

Sumber: Data diolah, 2018

Perhitungan return tak normal pada perusahaan-perusahaan yang secara terus menerus masuk ke dalam kelompok saham indeks IDX30 selama periode Pebruari2013 hingga 2018. PengujianPenelitian ini menggunakan teknik analisis data uji beda $t$-test. Tujuan dari pengujian ini yaitu untuk membuktikan apakah terdapat perbedaan abnormal return pada bulan Januari dibandingkan dengan bulan lainnya secara signifikan. Kedua sampel data ini yaituabnormal returnbulan lainnya (Pebruari hingga Desember) dan abnormal return bulan Januari. Proksi yang digunakan untuk menghitung abnormal return bulan selain Januari yaitu proksi average abnormal.

Pengujian hipotesis dilakukan setelah melakukan analisis deskriptif. Analisis deskriptif ini dilakukan untuk mengetahui definisi atau gambaran umum dari sampel yang diteliti. Penelitian ini bertujuan untuk mengetahui apakah terdapat perbedaan abnormal return bulan Januari dengan bulan lainnya yang dapat menimbulkan January Effect pada kelompok saham indeks IDX30. Penelitian ini menggunakan variabel abnormal return saham dengan proksi average abnormal return di bulan lainnya (Pebruari hingga Desember) dan abnormal return pada bulan Januari dari perusahaan-perusahaan yang berturutturut masuk ke dalam kelompok saham indeks IDX30 selama periode Pebruari 2013 hingga Januari 2018. Hasil analisis deskriptif average abnormal return pada bulan lainnya dan abnormal return pada bulan Januari dapat dilihat pada Tabel 3 sebagai berikut:

Tabel 3.

Analisis Deskriptif Average Abnormal Return pada Bulan Selain Januari dan Abnormal Return pada Bulan Januari Periode Pebruari 2013 Hingga Januari 2018

\begin{tabular}{lccccc}
\hline & N & Minimum & Maksimum & Mean & $\begin{array}{c}\text { Std. } \\
\text { Deviation }\end{array}$ \\
\hline AR Bulan Lainnya & 85 &,- 06 &, 10 &, 0010 &, 02193 \\
AR Januari & 85 &,- 37 &, 47 &, 0034 &, 10110 \\
Valid N (listwise) & 85 & & & & \\
\hline
\end{tabular}

Sumber: Data diolah, 2018 
Pada Tabel 3. dapat dilihat bahwa hasil analisis statistik deskriptif menunjukkan bahwa rata-ratareturntak normalsaham selama periode Pebruari 2013hingga Januari 2018, dimana rata-ratareturntak normaltertinggi terjadi pada bulan Januari yaitu 0,0034 dan rata-rata returntak normal terendah terjadi pada bulan lainnya yaitu sebesar 0,0010. Nilai maksimum dan minimum nilai returntak normalterendah selama periode Pebruari 2013 hingga Januari 2018 terjadi pada bulan Januari sebesar -0,37 dan nilai returntak normaltertinggi selama periode Pebruari 2013 hingga Januari 2018 juga terjadi pada bulan Januari yaitu sebesar 0,47 .

Nilai deviasi standar terkecil terdapat pada bulan lainnya yaitu sebesar 0,02193 . Hal tersebut menandakan bahwa bulan lainnya mempunyai tingkat risiko perdagangan yang rendah dibandingkan pada bulan januari namun, hal tersebut tidak terjadi pada bulan Januari, dimana bulan Januari memiliki nilai standar deviasi yang besar yaitu 0,10110 yang membuktikan bahwa bulan Januari memiliki tingkat risiko perdagangan yang tinggi.

Pada penelitian ini, penulis mengajukan hipotesis yaitu terdapat perbedaan abnormal returnpada bulan Januari dan bulan lainnya (Pebruari hingga Desember) saham kelompok indeks IDX30 di Bursa Efek Indonesia. Pengujian hipotesis ini dirancang untuk mengetahui apakah terjadi reaksi pada perusahaanperusahaan di Bursa Efek Indonesia yang masuk secara terus menerus ke dalam kelompok saham indeks IDX30 terhadap January Effect selama periode Pebruari 2013 hingga Januari 2018. Pengujian terhadap hipotesis meggunakan uji Paired Samples t-test. Hasil pengujian Paired Samples t-test menggunakan proksiAverage Abnormal Return sebelum dan sesudah January Effect dengan menggunakan Market Adjusted Model seperti pada Tabel 4 sebagai berikut:

Tabel 4.

Pengujian Beda Rata-Rata Abnormal Return pada Market-Adjusted Model Sebelum dan Sesudah January Effect Periode Pebruari 2013 - Januari 2018

\begin{tabular}{llcccc}
\hline & Mean & N & $\begin{array}{c}\text { Std. } \\
\text { Deviation }\end{array}$ & $\begin{array}{c}\text { Std. Error } \\
\text { Mean }\end{array}$ \\
\hline Pair 1 & AR Bulan Lainnya &, 0010 & 85 &, 02193 &, 00238 \\
& AR Januari &, 0034 & 85 &, 10110 &, 01097 \\
\hline
\end{tabular}

Sumber: Data diolah, 2018

Berdasarkan hasil pengujian menggunakan program SPSS 23 Tabel 4 membuktikan bahwa rata-rata abnormal return saham tertinggi terjadi pada bulan Januari yaitu sebesar 0,0034 dan terendah pada bulan laninnya (Pebruari hingga Desember) yaitu sebesar 0,0010 .

Tabel 5.

Pengujian Korelasi Sebelum dan Sesudah January Effect Periode Pebruari 2013 - Januari 2018

\begin{tabular}{llccc}
\hline & & N & Correlation & Sig. \\
\hline Pair 1 & AR Bulan Lainnya \& & 85 &,- 179 &, 100 \\
& AR Januari & 85 &
\end{tabular}

Sumber: Data diolah, 2018 
Hasil pengujian korelasi pada Tabel 5 membuktikan bahwa korelasi antara dua variabel yaitu sebesar -0,179 dengan nilai sig sebesar 0,100 dimana 0,100 > 0,05 artinya tidak terdapat hubungan korelasi antara sebelum dan sesudah January Effect. Hal ini ditunjukkan dengan peningkatan abnormal return saham sebesar $0,179^{2}$ atau $0,032(3,2 \%)$ akibat adanya fenomena January Effect.

Tabel 6.

Perbedaan Rata-Rata Abnormal Return Paired-Samples t-test Sebelum dan Sesudah January Effect Periode Pebruari 2013 - Januari 2018

\begin{tabular}{|c|c|c|c|c|c|c|c|c|c|}
\hline & & & & $\begin{array}{l}\text { Paired } \\
\text { ifferenc }\end{array}$ & & & & & \\
\hline & & & $\begin{array}{c}\text { Std. } \\
\text { Deviatio }\end{array}$ & $\begin{array}{c}\text { Std. } \\
\text { Error }\end{array}$ & $\begin{array}{r}95 \% \text { Co } \\
\text { Interva } \\
\text { Diffe }\end{array}$ & $\begin{array}{l}\text { fidence } \\
\text { of the } \\
\text { nce }\end{array}$ & & & Sig. (2- \\
\hline & & Mean & $\mathrm{n}$ & Mean & Lower & Upper & $\mathbf{T}$ & Df & tailed) \\
\hline $\begin{array}{l}\text { Pair } \\
1\end{array}$ & $\begin{array}{l}\text { AR Bln } \\
\text { Lainnya } \\
\text { - AR } \\
\text { Januari }\end{array}$ &,- 00242 & ,10723 & ,01163 &,- 02555 & ,02071 &,- 208 & 84 &, 835 \\
\hline
\end{tabular}

Sumber: Data diolah, 2018

Berdasarkan hasil Tabel 6. dengan menggunakan pengujian Paired Samples t-test di atas, dapat ditarik kesimpulan bahwa pada periode Pebruari 2013 hingga Januari 2018 sebelum dan sesudah January Effectyaitu rata-rata return tak normalsebelum dan sesudah January Effect pada periode Pebruari 2013 hingga Januari 2018 yaitu sebesar -0,00242 dengan standar deviasisebesar 0,10723 dan nilai t sebesar $-0,208$ dengan taraf signifikansi sebesar 0,835. Signifikansi (2tailed) menunjukkan 0,835 dimana $0,835>0,05$ maka tidak terdapat perbedaan yang signifikan pada abnormal return saham bulan Januari dengan bulan selain Januari pada kelompok saham indeks IDX30 di Bursa Efek Indonesia selama periode penelitian. Jadi, saham-saham yang tergabung ke dalam indeks IDX30 di Bursa Efek Indonesia selama periode Pebruari 2013 hingga Januari 2018 dapat dikatakan efisien dalam bentuk lemah.

Berdasarkan hasil pengujian yang telah dilakukan, menunjukkan bahwa hipotesis pengujian yang diajukan terkait fenomena January Effect ini ditolak, dimana artinya pada penelitian ini fenomena January Effecttidak terjadipada perusahaan kelompok saham indeks IDX30 selama periode Pebruari 2013 hingga Januari 2018. Terdapat perbedaan antara hasil penelitian ini dengan penelitianpenelitian yang telah dilakukan di beberapa negara seperti Amerika dan negara di kawasan Asia Pasifik yang hasilnya menunjukkan bahwa terjadi January Effect. Pada negara di kawasan Asia Pasifik penelitian dilakukan oleh Mangala \& Lohia (2013) didapatkan hasil yang bervariasi yaitu January Effect terjadi di Rusia tetapi tidak terjadi di Argentina, Brazil, China, India, Indonesia, Malaysia, Mexico, dan Taiwan. Fenomena tidak terjadinya January Effect sejalan dengan penelitian Atsin \& Ocran (2015) di Colombo Stock Exchange yang tidak menemukan adanya pola returntak normalsaham yang signifikan pada bulan Januari dan bulan lainnya. Selain itu, penelitian Idolor (2013) di Nigeria Stock Exchange, penelitian Yatiwella (2011) di Colombo Stock Exchange dan penelitian Luhan et al. (2011) 
di Prague Stock Exchange juga tidak menemukan adanya perbedaan return tak normal di bulan Januari dan bulan lainnya.

Hasil uji analisis deskriptif menunjukkan bahwa abnormal returnyang tinggi cenderung terjadi pada bulan Januari dibandingkan dengan bulan lainnya. Namun, hasil uji t berpasangan membuktikan tidak terdapat perbedaan yang signifikan antara abnormal return bulan Januari dengan bulan selain Januari. Hal yang sama ditemukan pada penelitian Iskamto (2015) dan Sari \& Sisdyani (2014) di pasar modal Indonesia bahwa tidak terdapat perbedaan return saham di bulan Januari dengan return saham bulan selain Januari. Selain itu, penelitian Harijanto \& Kurniawati (2013) juga tidak menemukan adanya fenomena January Effect pada Strait Times Index di Bursa Efek Singapura.

Pada penelitian periode Pebruari 2013 hingga Januari 2018 tidak terjadi January Effect yang menandakan bahwa pasar dapat dikatakan sudah efisien dalam bentuk lemah. Hal ini dikarenakan harga-harga saham di Bursa Efek Indonesia telah mencerminkan seluruh informasi pergerakan harga saham di masa lalu sehingga tidak ada satupun investor baik investor perorangan maupun investor institusional yang mendapatkan informasi lebih dan memanfaatkan informasi yang tersebut untuk mendapatkan abnormal return di bulan Januari yang dapat menyebabkan timbulnya January Effect.

Tidak terjadinya fenomena January Effect menandakan bahwa sahamsaham yng berada pada kelompok indeks IDX30 memiliki kapitalisasi pasar yang tinggi, hal ini berarti saham berkinerja dengan baik dan memberikan tingkat pengembalian yang menjanjikan kepada investor. Selain itu, tahun pajak di Indonesia bukan terjadi pada akhir bulan Desember, akan tetapi tahun pajak di Indonesia terjadi pada bulan Maret. Hal ini terkait dengan praktik window dressing dimana fund manager melakukan perbaikan laporan tahunan keuangan kepada investor agar tampak lebih baik. Praktik window dressing ini dilakukan dengan cara menjual saham yang berkinerja buruk yang kemudian digunakan untuk membeli saham berkinerja baik (winning stock). Aksi beli saham berkinerja baik ini diharapkan dapat meningkatkan kinerja reksadana. Namun, dalam hal ini investor tidak perlu melakukan aksi jual beli saham secara cepat di akhir tahun kemudian membeli saham di awal tahun karena saham-saham yang berada pada kelompok indeks IDX30 merupakan saham yang memiliki kinerja yang baik dan menjanjikan tingkat pengembalian kepada investor. Selain itu, perbedaan budaya dimana umumnya libur natal dan tahun baru terjadi lebih panjang di Amerika atau negara barat lainnya dibandingkan Indonesia sehingga umumnya jangka waktu investasi memengaruhi tingkat pengembalian yang akan didapatkan investor.

IDX30 adalah indeks yang terdiri dari 30 saham perusahaan yang dipilih dari kelompok Indeks LQ45, dimana memiliki total hari transaksi, nilai dan aktivitas transaksi saham tinggi, serta kapitalisasi pasar yang tinggi sehingga dapat dikatakan indeks IDX30 merupakan indeks yang cukup sensitif terhadap informasi-informasi pasar. Pada penelitian ini dapat terlihat bahwa kelompok saham indeks IDX30 periode Pebruari 2013 hingga Januari 2018 tidak terdapat fenomena January Effect yang artinya pasar dapat dikatakan efisien dalam bentuk lemah. Hal ini dapat dilihat pada Tabel 4. dimana pergerakan abnormal return dapat dikatakan tidak begitu ekstrim. Hal ini dapat dikarenakan beberapa 
fenomena yang terjadi seperti pada tahun 2013 perekonomian dalam negeri yang tidak memenuhi target, terutama defisit neraca transaksi berjalan dan neraca perdagangan.Hal ini juga terlihat dari tingginya tingkat penjualan oleh investor asing di Bursa Efek Indonesia (BEI). Terjadinya fenomena dimana nilai rupiah jatuh terhadap dolar Amerika Serikat di sepanjang tahun 2015. Depresiasi nilai tukar rupiah terjadi akibat berkurangnya arus modal asing ke Indonesia akibat sentimen global, khususnya normalisasi kebijakan moneter Bank Sentral AS dan devaluasi mata uang China, yuan. Fenomena ini masih terasa hingga awal tahun 2016.

\section{SIMPULAN DAN SARAN}

Berdasarkan hasil penelitian yang telah dilakukan, maka dapat ditarik kesimpulan bahwa tidak terdapat perbedaan abnormal return saham pada bulan Januari dengan bulan lainnya di Bursa Efek Indonesia khususnya pada kelompok saham Indeks IDX30 selama periode Pebruari 2013 hingga Januari 2018. Hal ini menunjukkan bahwa kelompok saham indeks IDX30 memiliki kapitalisasi pasar yang tinggi sehingga menyebabkan saham-saham yang bergabung pada indeks tersebut memiliki kinerja yang baik dan menjanjikan tingkat pengembalian yang cukup tinggi kepada investor. Sehingga investor tidak memerlukan adanya fenomena January Effect untuk mendapatkan keuntungan yang lebih. Jadi, dapat dikatakan fenomena January Effect tidak terjadi di pasar modal Indonesia selama periode Pebruari 2013 hingga Januari 2018

Bagi investor yang ingin melakukan kegiatan investasi sebaiknya tidak bergantung pada fenomena January Effect. Investor lebih baik mempertimbangkan faktor fundamental serta pertumbuhan ekonomi baik secara mikro ataupun makro sebelum melakukan kegiatan investasi.

Variabel yang digunakan pada penelitian ini yaitu return bulanan, return market, dan return tak normal saham sedangkan terdapat variabel lainnya yang dapat digunakan seperti expected return. Bagi peneliti selanjutnya diharapkan dapat memperluas jenis perusahaan pada indeks yang berbeda serta periode pengamatan dan tempat penelitian yang berbeda, sehingga mampu memberikan pertimbangan bagi perusahaan maupun investor.

\section{REFERENSI}

Alteza, M. (2007). Efek Hari Perdagangan Terhadap Return Saham: Suatu Telaah atas Anomali Pasar Efisien. Jurnal Ilmu Manajemen, 3(1), 31-43.

Angelovska, J. (2014). Month Related Seasonality on the Macedonian Stock Market. Business and Economics Research Journal, 5(1), 143-150 ISSN: 1309-2448.

Atsin, J. A. L., \& Ocran, M. K. (2015). Calendar Effects and Market Anomalies on the Johannesburg Stock Exchange. Munich Personal RePEc Archive(MPRA) University of the Western Cape, (87448), 1-31. website: https://mpra.ub.uni-muenchen.de/87448/

Chou, J., Praveen K. D. \& S. P. Uma Rao. (2011). The Value Premium and the 
January Effect. Managerial Finance, 37(6), 517-536. https://doi.org/10.1108/03074351111134727

Compton, W., Kunkel, R. A., \& Kuhlemeyer, G. (2013). Calendar anomalies in Russian stocks and bonds. Managerial Finance, 39(12), 1138-1154. https://doi.org/10.1108/MF-03-2013-0067

Darrat, A. F., Bin Li, \& Chung, R. (2013). Seasonal Anomalies : A Closer Look at the Johannesburg Stock Exchange. Contemporary Management Research, 9(2), 155-168. https://doi.org/10.7903/cmr.10629

Deannes, P. C. P. \& Isynuwardhana. (2015). January Effect pada Perusahaan LQ 45 Di Bursa Efek Indonesia Periode 2009 - 2013. E-Proceeding of Management, 2(1), 524-538 ISSN: 2355-9357.

Fama, E. F. (1970). Efficient Capital Markets: A Review of Theory and Empirical Work. The Journal of Finance, 25(2), 383-417.

Fauzi, N. (2007). Analisis Fenomena Anomali Pasar January Effect dan Korelasi diantara Tiga Emerging Stock Market Asia Periode 2000-2006. Jurnal Akuntansi \& Manajemen, 2(2), 63-77.

Fitriyani, I., \& Sari, M. M. R. (2013). Analisis January Effect pada Kelompok Saham Indeks LQ-45 di Bursa Efek Indonesia Tahun 2009-2011. E-Jurnal Akuntansi Universitas Udayana, 4(2), 421-438 ISSN: 2302-8556.

Hamid, Shaikh A. \& Habisb, A. (2017). The Behavior of Total Monthly Returns of Small Stocks. International Research Journal of Applied Finance, 7(9), 590-603 ISSN: 229-6891.

Harijanto, C. A., \& Kurniawati, S. L. (2013). Pengujian Market Efficincy: Pembuktian Fenomena Anomali Pasar pada Strait Times Index di Bursa Efek Singapura. Journal of Business and Banking, 3(2), 223-232. https://doi.org/10.14414/jbb.v3i2.239

Hartono, Jogiyanto. (2017). Teori Portofolio dan Analisis Investasi. Edisi Kesepuluh. Yogyakarta: BPFE.

Husnan, Suad. (2005). Dasar-Dasar Teori Portofolio dan Analisis Sekuritas Edisi Keempat; Cetakan Pertama. UPP AMP.

Idolor, E. J. (2013). Testing Calendar Effect on Nigerian Stock Market Returns : Methodologica Approach. Journal of Financial Management \& Analysis, 26(1), 39-64.

Iskamto, D. (2015). Anomali Pasar pada Bursa Efek Indonesia. Jurnal Tepak Manajemen Bisnis, 7(3), 388-398. 
Jaisinghani, D. (2016). An Empirical Test of Calendar Anomalies for the Indian Securities Markets. South Asian Journal of Global Business Research, 5(1), 53-84. https://doi.org/10.1108/SAJGBR-07-2014-0050

Jones, Charles P., (2014). Investments Principle and Concepts. Twelfth Edition. Singapura: John Wiley and Sons Singapore Pte. Ltd.

Kadir, S. \& Suramaya S. K. (2014). Fenomena January Effect di Bursa Efek Indonesia (Studi pada Perusahaan yang Terdaftar di LQ45 Periode 20102013). Jurnal Keuangan dan Bisnis, 12(1), 125-140.

Kartikasari, L. H. (2017). Pengujian January Effect : Studi komparasi pada Bursa Efek Indonesia dan Bursa Saham Shanghai periode 2011-2013, 6(1), 6580. https://doi.org/10.14414/jbb.v6i1.657

Kemal \& Sinem. (2016). Examining the January Effect in Borsa Istanbul Sector and Subsector Indices. International Journal of Economi Perspective, 10(2), 102-109 ISSN: 1307-1637.

Luhan, J., Novotná, V., \& Obrová, V. (2011). January Effect at the Czech Capital Market. Intelectual Economics, 5(12), 602-612 ISSN: 1822-8038 .

Mangala, D., \& Lohia, V. (2013). Market Efficiency in Emerging Economies : An Empirical Analysis of Month-of-the-Year Effect. The IUPJournal of Applied Finance, 19(3), 19-38.

Patel, J. B. (2016). The January Effect Anomaly Reexamined in Stock Returns. The Journal of Applied Business Research, 32(1), 317-324.

Pradnyaparamita, N. M. W., \& Rahyuda, H. (2017). Pengujian Anomali Pasar January Effect pada Perusahaan LQ45 di Bursa Efek

Indonesia. E-Jurnal Manajemen UniversitasUdayana, 6(7), 3513-3539 ISSN: 2302-8912.

Pratomo, Agus Wahyu. (2007). January Effect dan Size Effect pada Bursa Effect Jakarta (BEJ) Periode 1998-2005. Tesis Magister Manajemen pada Fakultas Ekonomi Universitas Diponegoro. website: http://eprints.undip.ac.id/17919/

Sari, F. A., \& Sisdyani, E. A. (2014). Analisis January Effect di Pasar Modal Indonesia. E-Jurnal Akuntansi Universitas Udayana, 6(2), 237-248 ISSN: 2302-8556.

Sriram, M., \& Devi, P. R. (2013). Seasonality in the Returns : A Study of BSE Sensex. International Journal of Financial Management, 3(1), 60-69.

Sudarvel, J. \& R. Velmurugan. (2015). January Effect in Indian Banking Sector 
with Reference to BSE Bank Index. International Journal of Management Research \& Review, 5(11), 1066-1071 ISSN: 2249-7169.

Sunariyah. (2011). Pengantar Pengetahuan Pasar Modal. Edisi Keenam. Yogyakarta: UPP STIM YKPN.

Surjoko, F. O. (2014). Efek Bulan Januari (The January Effect). Bina Ekonomi Majalah Ilmiah Fakultas Ekonomi Universitas Katolik Parahyangan, 18(1), 117-123.

Tandelilin, Eduardus. (2010). Portofolio dan Investasi. Edisi Pertama. Yogyakarta: Kanisius.

Yatiwella, W. B. \& J. L. N. De Silva. (2011). Calendar Anomalie: Evidence from the Colombo Stock Exchange. Economics, Management, and Financial Markets, 6(2), 84-105 ISSN: 1842-3191..

www.idx.co.id, diakses pada Mei 2018

www.yahoo.finance.com, diakses pada September 2018 